\title{
Disposition of Ipriflavone (TC-80) in Rats and Dogs
}

\author{
Kiyoshi Yoshida, Takeji Tsukamoto, Hiroshi ToRII, Takayoshi DoI, \\ Ichiro NAESHIRo, Kunihiko SHIBATA*, Ieaki UEMURA* \\ and Shigeharu TANAYAMA \\ Central Research Division, Takeda Chemical Industries, Ltd. \\ 17-85, Jusohonmachi 2-chome, Yodogawa-ku, Osaka-shi 532 \\ *NRI Life Science 7-1, Kajiwara 4-chome, Kamakura-shi 247 \\ Received June 21, 1985
}

\begin{abstract}
Oral ${ }^{14} \mathrm{C}$-ipriflavone was absorbed by rats to give a maximum plasma ${ }^{14} \mathrm{C}$ level at $1.5 \mathrm{~h}$ and a half-life of $5.8 \mathrm{~h}$. In dogs, after po dosing, the plasma ${ }^{14} \mathrm{C}$ peaked at $0.5 \mathrm{~h}$, followed by gradual decline. The plasma of both animals contained mostly metabolites, with small amounts of unchanged ipriflavone. In rats, ${ }^{14} \mathrm{C}$ was distributed widely in tissues, with relatively high concns. in the liver, kidney and gut. Distribution in rat thigh bone of unmetabolized ipriflavone was also demonstrated. ${ }^{14} \mathrm{C}-I$-Ipriflavone was eliminated mostly as metabolites within 48 and $72 \mathrm{~h}$, respectively, in rats and dogs. Rats excreted more ${ }^{14} \mathrm{C}$ in urine than in feces, whereas the reverse was noted in dogs. Biliary excretion and reabsorption of ${ }^{14} \mathrm{C}$ were also obvious in both animals.
\end{abstract}

Key Words: ipriflavone, rat, dog, distribution, excretion, metabolite

\section{Introduction}

Ipriflavone (7-isopropoxyisoflavone, TC-80), a synthetic flavonoid, is considered to be a highly promising agent being effective in the treatment of osteoporosis ${ }^{1-3)}$. In our previous work $^{4)}$, identification of TC-80 metabolites led to the conclusion that the compound was metabolized by oxidation: (1) elimination of the isopropyl group, (2) oxidation of the isopropyl function, and (3) hydroxylation of the $B$ ring. The present paper describes the absorption, distribution and elimination of ${ }^{14} \mathrm{C}$-ipriflavone $\left({ }^{14} \mathrm{C}-\mathrm{TC}-80\right)$ in rats and dogs, with thin-layer chromatographic (TLC) and high-performance liquid chromatographic (HPLC) analysis of TC-80 and its metabolites in body fluids tissues and excreta.

\section{Materials and Methods}

\subsection{Materials}

TC-80, nonlabeled or ${ }^{14} \mathrm{C}$-labeled, 7-hydroxy3-phenyl-4H-1-benzopyran-4-one(I), 7-hydroxy-3(4-hydroxyphenyl)-4H-1-benzopyran-4-one(II), 3(4-hydroxyphenyl)-7-isopropoxy-4H-1-benzopyran4-one (III), 2-(3-phenyl-4-oxo-4 $H$-1-benzopyran-7- yl)oxypropyl alcohol (IV), 2-(3-phenyl-4-oxo-4 $\mathrm{H}^{-}$ 1-benzopyran-7-yl)oxypropionic $\operatorname{acid}(\mathrm{V}), 2-[3-(4-$ hydroxyphenyl)-4-oxo-4H-1-benzopyran-7-yl]-oxypropionic acid (V) and 2-[3-(3-hydroxyphenyl)4-oxo-4H-1-benzopyran-7-yl]oxypropionic acid (VII) were as used in the preceding paper ${ }^{4}$. All other reagents used were of analytical grade.

2.2 Animals, dosing and sample collection Male Jc1:Wistar rats $(208-277 \mathrm{~g}$, CLEA Japan Inc., Tokyo) and male beagle dogs (9.8 $12.0 \mathrm{~kg}$, CLEA Japan Inc.) were used. ${ }^{14} \mathrm{C}-$ TC-80 diluted appropriately with the nonlabeled compound was suspended in $1 \%$ hydroxypropylcellulose solution for oral (po), intragastric (ig) or intraduodenal (id) administration to the animals, fasted overnight, at a single dose of $20 \mathrm{mg} / \mathrm{kg}$, unless otherwise noted. After dosing, body fluids, tissues, respiratory air and excreta were collected according to the methods described previously $y^{5)-7}$. The portal blood was collected from the rat with jejunal loop ${ }^{\text {a) }}$.

\subsection{Analytical methods}

Carbon-14 in biological samples, organic solvent extracts, silica gel from TLC plates and eluent in HPLC was determined by liquid 
scintillation spectrometry ${ }^{4}$.

${ }^{14} \mathrm{C}-\mathrm{TC}-80$ and its metabolites in biological specimens were quantified by the combined use of TLC and HPLC. The plasma and aqueous homogenates of tissues and feces were extracted with acetone $(5 \mathrm{vol} . \times 1)$. Aliquots of urine, bile and the acetone extracts were then submitted to TLC using precoated silica gel $60 \mathrm{~F}_{254}$ plates $(0.25 \mathrm{~mm}$ thick; E Merck, Darmstadt, FR Germany) developed one-dimensionally in the system $\mathrm{A}^{4)}$ or two-dimensionally, first in the system $\mathrm{B}^{4)}$ and then in the system $\mathrm{C}$ (chloroform-acetone-acetic acid $=100: 100: 1, \mathrm{v} / \mathrm{v})$. Figure 1 depicts a typical two-dimensional thinlayer chromatogram showing separation of TC80 and its metabolites. After development, ${ }^{14} \mathrm{C}-\mathrm{TC}-80$ and metabolites on the plates were located by autoradiography using X-ray film (RX; Fuji Photo Film Co. Ltd., Tokyo) and/or UV absorption of authentic compounds added to the test samples as internal standards. The silica gel sections that corresponded to the compounds of interest were removed from the plate and counted. The remainder materials on the plate were removed, counted and referred to as "other metabolites". Amounts of VI and III (unresolved by TLC) were determined by HPLC using a Waters apparatus (Waters model 6000 A; Waters Assoc., Milford, Mass., U.S.A.). The silica gel sections containing II and III

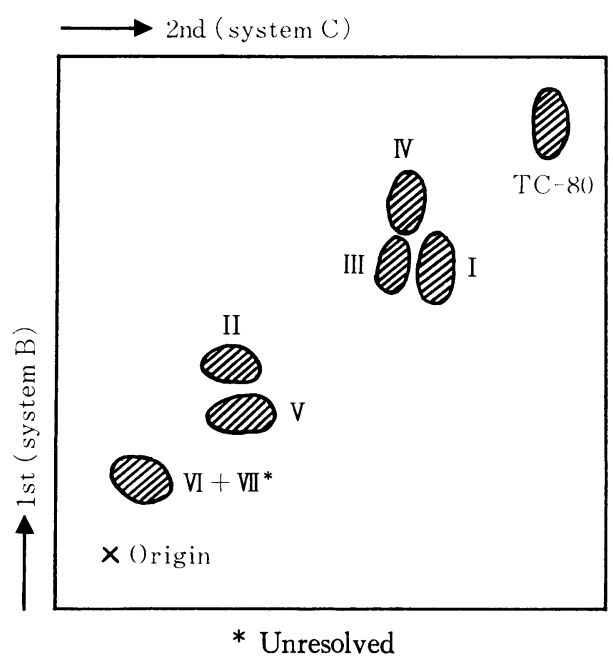

Fig. 1 Two-dimensional TLC showing separation of TC- 80 and its metabolites. were removed from the plates, suspended in $0.05 N \mathrm{HCl}$ and extracted with ethyl acetate $(3$ vol. $\times 3)$. The solvent extracts, after evaporation, were redissolved in a mobile phase (described below) and injected onto an HPLC column (Waters Radial-Pak 8NVC185 $\mu, 100 \times$ $8 \mathrm{~mm}$ I.D.) eluted at a rate of $1 \mathrm{ml} / \mathrm{min}$ with a mixture of acetonitrile-1\% acetic acid (2:3, $\mathrm{v} / \mathrm{v})$. Chromatography was carried out at an ambient temperature. II and VII with the respective retention times of 11.2 and $12.5 \mathrm{~min}$ were monitored, collected and counted. To determine conjugated metabolites, the samples were treated with $\beta$-glucuronidase containing phenol sulfatase (Type $\mathrm{H}-1$, from Helix pomatia; Sigma Chemical Co., St. Louis, Mo., U.S.A.) for $16 \mathrm{~h}$ at $37^{\circ} \mathrm{C}$. Conjugated metabolites were calculated by measuring the metabolites in the samples before and after the enzyme treatment.

\subsection{Plasma protein binding}

Binding of ${ }^{14} \mathrm{C}-\mathrm{TC}-80$ to the plasma protein was estimated by the ultracentrifugation method. The plasma of rats and dogs, to which the labeled compound was added in vitro at concentrations of $0.1,1$ and $10 \mu \mathrm{g} / \mathrm{ml}$, was centrifuged for $6 \mathrm{~h}$ at $65000 \mathrm{rpm}$ by using a refrigerated ultracentrifuge (Hitachi model 65P or HPC $70 \mathrm{H}$ with a model RP-65T angle rotor, Hitachi Ltd., Tokyo).

\subsection{Whole-body autoradiography}

Whole-body sections ( $40 \mu \mathrm{m}$ thick) of rats were prepared at $15 \mathrm{~min}, 1.5,8$ and $48 \mathrm{~h}$ after po administration of ${ }^{14} \mathrm{C}-\mathrm{TC}-80$ by the method reported previously ${ }^{6)}$ and exposed to $\mathrm{X}$-ray film (IX; Fuji Photo Film Co., Ltd.) for 6 weeks at $25^{\circ} \mathrm{C}$.

\subsection{Data processing}

Data are expressed as the means with the standard deviations (S.D.) for three or four animals, unless otherwise indicated. Plasma half-life and area under the plasma level-time curves (AUC) were calculated by linear regression analysis and trapezoidal rule, respectively.

\section{Results and Discussion}

\subsection{Absorption}

After po dosing of ${ }^{14} \mathrm{C}-\mathrm{TC}-80$ to rats, $40.4 \%$ 
of the ingested ${ }^{14} \mathrm{C}$ was excreted in the $0-24 \mathrm{~h}$ feces, of which $50.2 \%$ consisted of the unaltered compound (Table 4). It was thus calculated that in this species $20.3 \%$ of ${ }^{14} \mathrm{C}-\mathrm{TC}$ 80 dosed po was excreted in feces unchanged. In dogs, $75.5 \%$ of po ${ }^{14} \mathrm{C}-\mathrm{TC}-80$ was excreted in the $0-48 \mathrm{~h}$ feces unchanged (Table 4). From the amount of unaltered ${ }^{14} \mathrm{C}-\mathrm{TC}-80$ recovered in feces, approximately 80 and $24 \%$ of the ingested compound were considered to be absorbed, respectively, in rats and dogs. As described later, it was already confirmed that no significant amount of unmetabolized ${ }^{14} \mathrm{C}$ TC-80 was excreted in bile of rats and dogs, and also that the compound did not undergo metabolic conversion in the gut of both animals.

The site of absorption was assessed by measuring plasma ${ }^{14} \mathrm{C}$ for $4 \mathrm{~h}$ after ig or id administration of ${ }^{14} \mathrm{C}-\mathrm{TC}-80$ to pylorus-ligated rats (Fig. 2). Id administration of the compound was followed by a prompt rise in plasma ${ }^{14} \mathrm{C}$ level, which peaked at $0.5 \mathrm{~h}(2.74 \mu \mathrm{g} \mathrm{TC}-$ 80 equivalents $/ \mathrm{ml}$ ) and then decreased with a half-life of $8.9 \mathrm{~h}$. Plasma levels after ig administration were invariably much lower $(<0.03 \mu \mathrm{g}$ TC -80 equivalent $/ \mathrm{m} l)$ than those after id dosage. It was thus obvious that oral TC-80 was absorbed exclusively from the small intestine.

After po administration of ${ }^{14} \mathrm{C}-\mathrm{TC}-80$ to thoracic-duct fistulated rats, only $0.61 \pm 0.03 \%$ of the ingested ${ }^{14} \mathrm{C}(n=3)$ was recovered from

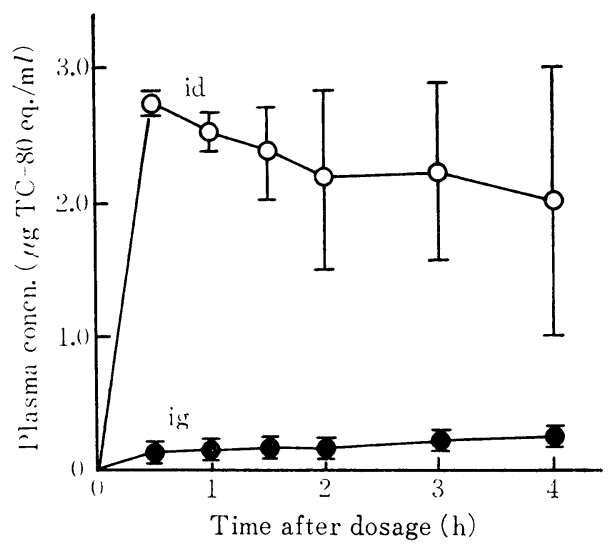

Data are the mean \pm S.D. of four rats

Fig. 2 Plasma levels of radioactivity after ig or id administration of ${ }^{14} \mathrm{C}-\mathrm{TC}-80$ to pylorusligated rats. the lymph collected for $24 \mathrm{~h}$, showing that the lymphatic route was unlikely for absorption of $\mathrm{TC}-80$. Within $2 \mathrm{~h}$ after instillation of ${ }^{14} \mathrm{C}-$ TC-80 $(2 \mathrm{mg} / \mathrm{kg})$ into the jejunal loop of a rat, $20.5 \%$ of the dosed ${ }^{14} \mathrm{C}$ was absorbed into the portal blood. In addition, $98 \%$ of the ${ }^{14} \mathrm{C}$ in the portal blood was unmetabolized TC-80 as demonstrated by TLC analysis. These findings indicated that TC- 80 was absorbed unchanged predominantly via the portal route.

\section{$3 \cdot 2$ Plasma level}

After po administration of ${ }^{14} \mathrm{C}-\mathrm{TC}-80$ to rats, the plasma level of ${ }^{14} \mathrm{C}$ attained a peak $(5.40 \mu \mathrm{g}$ TC-80 equivalents $/ \mathrm{m} l)$ at $1.5 \mathrm{~h}$ and then decreased with an apparent half-life of $5.8 \mathrm{~h}$ (Fig. 3A). In dogs, after po administration, the plasma ${ }^{14} \mathrm{C}$ reached a maximum $(1.32 \mu \mathrm{g}$ TC -80 equivalents $/ \mathrm{m} l$ ) at $0.5 \mathrm{~h}$, followed by gradual decline to extremely low level at $48 \mathrm{~h}$ (Fig. 3B).

TLC analysis showed that in both rats and dogs unchanged TC- 80 was the minor plasma components, with the remainder consisting of metabolites (Table 1). The metabolites found in plasma were $I, I I, \mathbb{I}, \mathbb{I}, \nabla$ and $\mathrm{II}+\mathrm{VII}$ (unresolved, Fig. 1), of which I, II and II + VII were predominant in rats, and $I$ in dogs. As demonstrated by

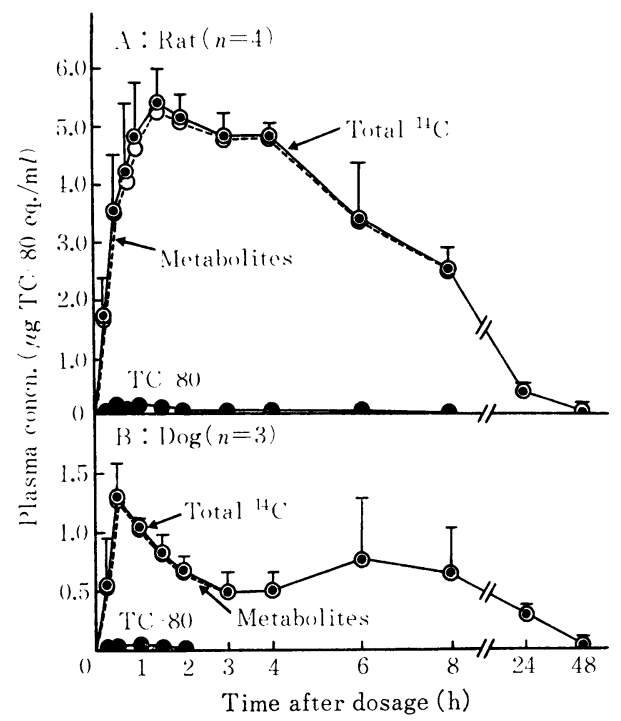

Radioactive concns. are the mean \pm S.D. of three or four animals, and levels of TC-80 and metabolites are for pooled samples.

Fig. 3 Plasma levels of ${ }^{14} \mathrm{C}-\mathrm{TC}-80$ and its metabolites after po administration to rats and dogs. 
Table 1 Composition of ${ }^{14} \mathrm{C}$-materials in plasma after po administration of ${ }^{14} \mathrm{C}-\mathrm{TC}-80$ to rats and dogs

\begin{tabular}{|c|c|c|}
\hline \multirow{2}{*}{ Compound } & \multicolumn{2}{|c|}{$\mathrm{AUC}_{0}^{24}(\mu \mathrm{g} \mathrm{h} / \mathrm{ml})$} \\
\hline & Rat & Dog \\
\hline Total ${ }^{14} \mathrm{C}$ & $55.30(100.0)$ & $13.00(100.0)$ \\
\hline TC-80 & $0.92(1.7)$ & $0.02(0.2)$ \\
\hline I & $14.75(26.7)$ & $7.58(58.3)$ \\
\hline II & $7.91(14.3)$ & $0.44(3.4)$ \\
\hline III & $0.97(1.8)$ & $0.36 C$ \\
\hline IV & $0.70(1.3)$ & $0.16 C$ \\
\hline$\nabla$ & $4.14(7.5)$ & $0.41(3.2)$ \\
\hline II + VII & $11.21(20.3)$ & $0.41(3.2)$ \\
\hline Others & $14.70(26.4)$ & $3.62(27.7)$ \\
\hline
\end{tabular}

Data are values for pooled samples of the animals shown in Fig. 3.

HPLC analysis, the fractions of $\nabla+V I$ in the $0.5,1.5$ and $6 \mathrm{~h}$ plasma of rats consisted mostly ( $>93 \%)$ of VII.

From these plasma level studies, it was obvious that $\mathrm{TC}-80$ was rapidly and extensively metabolized in both rats and dogs for subsequent gradual elimination from the bodies.

\subsection{Distribution}

A preliminary study of tissue distribution of po ${ }^{14} \mathrm{C}-\mathrm{TC}-80$ in rats by whole-body autoradiography indicated that the peak levels of ${ }^{14} \mathrm{C}$ were noted generally at $1.5 \mathrm{~h}$, with relatively high concentrations in the liver and kidney, and fell off gradually to very low levels at $48 \mathrm{~h}$. Based on these findings, tissue levels of ${ }^{14} \mathrm{C}$, TC-80 and metabolites were then estimated at 1.5 and $6 \mathrm{~h}$ after po administration of the labeled compound (Table 2). At these times, the levels of ${ }^{14} \mathrm{C}$ were highest in the intestine and lowest in the brain, with liver, stomach, kidney, plasma, lung, heart and thigh bone occupying intermediately positions in the order listed. The unaltered compound was distributed in all tissues examined, with the concentrations almost equal to or higher than that in the plasma. Almost all the metabolites found in plasma were also detectable in tissues.

\subsection{Plasma protein binding}

A study using ${ }^{14} \mathrm{C}-\mathrm{TC}-80$ in vitro showed that the compound was $87 \%$ bound in rats and $97 \%$ in dogs.

\subsection{Excretion}

\subsubsection{Urinary and fecal excretion}

After po administration of ${ }^{14} \mathrm{C}-\mathrm{TC}-80$, elimination of ${ }^{14} \mathrm{C}$ was almost complete within $48 \mathrm{~h}$ in rats and $72 \mathrm{~h}$ in dogs (Table 3 ). In rats, more ${ }^{14} \mathrm{C}$ was excreted in urine than in feces, whereas the reverse was noted in dogs. No

Table 2 Tissue levels of ${ }^{14} \mathrm{C}-\mathrm{TC}-80$ and its metabolites after po administration to rats

\begin{tabular}{|c|c|c|c|c|c|c|c|c|c|c|}
\hline \multirow{2}{*}{ Tissue } & \multirow{2}{*}{$\begin{array}{l}\text { Time after } \\
\text { dosage }(\mathrm{h})\end{array}$} & \multicolumn{9}{|c|}{ Tissue concn. ( $\mu \mathrm{g} \mathrm{TC}-80$ eq. $/ \mathrm{ml}$ or $\mathrm{g})$ of : } \\
\hline & & Total ${ }^{14} \mathrm{C}$ & TC-80 & I & II & III & IV & $\nabla$ & $\mathrm{VI}+\mathrm{VII}$ & Others \\
\hline Plasma & 1.5 & $\begin{array}{l}\text { 4. } 45 \pm 1.15 \\
\text { 3. } 07 \pm 0.64\end{array}$ & $\begin{array}{l}0.10 \\
0.04\end{array}$ & $\begin{array}{l}1.12 \\
0.36\end{array}$ & $\begin{array}{l}0.83 \\
0.46\end{array}$ & $\begin{array}{l}0.16 \\
0.04\end{array}$ & $\begin{array}{l}0.05 \\
0.02\end{array}$ & $\begin{array}{l}0.49 \\
0.21\end{array}$ & $\begin{array}{l}0.67 \\
0.84\end{array}$ & $\begin{array}{l}1.03 \\
1.10\end{array}$ \\
\hline Brain & $\begin{array}{c}1.5 \\
6\end{array}$ & $\begin{array}{l}0.39 \pm 0.16 \\
0.12 \pm 0.01\end{array}$ & $\begin{array}{l}0.20 \\
0.04\end{array}$ & $\begin{array}{l}0.04 \\
0.02\end{array}$ & $\begin{array}{l}0.01 \\
0.01\end{array}$ & $\begin{array}{l}0.01 \\
0.01\end{array}$ & $\begin{array}{r}0.08 \\
<0.01\end{array}$ & $\begin{array}{l}<0.01 \\
<0.01\end{array}$ & $\begin{array}{r}<0.01 \\
0.01\end{array}$ & $\begin{array}{l}0.05 \\
0.03\end{array}$ \\
\hline Heart & $\begin{array}{c}1.5 \\
6\end{array}$ & $\begin{array}{l}1.02 \pm 0.30 \\
0.50 \pm 0.11\end{array}$ & $\begin{array}{l}0.28 \\
0.07\end{array}$ & $\begin{array}{l}0.20 \\
0.07\end{array}$ & $\begin{array}{l}0.10 \\
0.05\end{array}$ & $\begin{array}{l}0.04 \\
0.02\end{array}$ & $\begin{array}{r}0.06 \\
<0.01\end{array}$ & $\begin{array}{l}0.07 \\
0.03\end{array}$ & $\begin{array}{l}0.07 \\
0.05\end{array}$ & $\begin{array}{l}0.20 \\
0.21\end{array}$ \\
\hline Lung & 1.5 & $\begin{array}{l}1.27 \pm 0.39 \\
0.65 \pm 0.17\end{array}$ & $\begin{array}{l}0.26 \\
0.06\end{array}$ & $\begin{array}{l}0.33 \\
0.09\end{array}$ & $\begin{array}{l}0.14 \\
0.09\end{array}$ & $\begin{array}{l}0.06 \\
0.03\end{array}$ & $\begin{array}{l}0.08 \\
0.01\end{array}$ & $\begin{array}{l}0.06 \\
0.03\end{array}$ & $\begin{array}{l}0.07 \\
0.06\end{array}$ & $\begin{array}{l}0.27 \\
0.28\end{array}$ \\
\hline Liver & 1.5 & $\begin{array}{r}14.88 \pm 5.69 \\
5.73 \pm 1.03\end{array}$ & $\begin{array}{l}4.55 \\
0.95\end{array}$ & $\begin{array}{l}3.37 \\
1.46\end{array}$ & $\begin{array}{l}0.34 \\
0.24\end{array}$ & $\begin{array}{l}2.49 \\
0.82\end{array}$ & $\begin{array}{l}0.53 \\
0.09\end{array}$ & $\begin{array}{l}1.01 \\
0.63\end{array}$ & $\begin{array}{l}0.58 \\
0.44\end{array}$ & $\begin{array}{l}1.96 \\
1.10\end{array}$ \\
\hline Kidney & $\begin{array}{c}1.5 \\
6\end{array}$ & $\begin{array}{l}8.79 \pm 2.10 \\
4.94 \pm 0.52\end{array}$ & $\begin{array}{l}0.24 \\
0.07\end{array}$ & $\begin{array}{l}4.47 \\
1.69\end{array}$ & $\begin{array}{l}0.93 \\
0.69\end{array}$ & $\begin{array}{l}0.55 \\
0.36\end{array}$ & $\begin{array}{l}0.19 \\
0.07\end{array}$ & $\begin{array}{l}1.03 \\
0.48\end{array}$ & $\begin{array}{l}0.39 \\
0.48\end{array}$ & $\begin{array}{l}0.99 \\
1.10\end{array}$ \\
\hline Stomach & $\begin{array}{c}1.5 \\
6\end{array}$ & $\begin{array}{r}12.12 \pm 5.32 \\
4.28 \pm 1.17\end{array}$ & $\begin{array}{r}10.33 \\
2.09\end{array}$ & $\begin{array}{l}0.70 \\
0.99\end{array}$ & $\begin{array}{l}0.15 \\
0.12\end{array}$ & $\begin{array}{l}0.24 \\
0.24\end{array}$ & $\begin{array}{l}0.08 \\
0.06\end{array}$ & $\begin{array}{l}0.04 \\
0.06\end{array}$ & $\begin{array}{l}0.10 \\
0.22\end{array}$ & $\begin{array}{l}0.48 \\
0.50\end{array}$ \\
\hline Intestine & 1.5 & $\begin{array}{l}22.87 \pm 15.55 \\
29.23 \pm 7.96\end{array}$ & $\begin{array}{l}7.09 \\
0.38\end{array}$ & $\begin{array}{r}8.07 \\
14.94\end{array}$ & $\begin{array}{l}0.48 \\
1.08\end{array}$ & $\begin{array}{l}2.17 \\
3.01\end{array}$ & $\begin{array}{l}0.41 \\
0.38\end{array}$ & $\begin{array}{l}0.39 \\
0.73\end{array}$ & $\begin{array}{l}0.87 \\
3.07\end{array}$ & $\begin{array}{l}3.39 \\
5.64\end{array}$ \\
\hline Thigh bone & 1.5 & $\begin{array}{l}0.37 \pm 0.11 \\
0.47 \pm 0.04\end{array}$ & $\begin{array}{l}0.05 \\
0.15\end{array}$ & $\begin{array}{l}0.10 \\
0.08\end{array}$ & $\begin{array}{l}0.04 \\
0.05\end{array}$ & $\begin{array}{l}0.02 \\
0.01\end{array}$ & $\begin{array}{r}0.02 \\
<0.01\end{array}$ & $\begin{array}{l}0.02 \\
0.02\end{array}$ & $\begin{array}{l}0.02 \\
0.02\end{array}$ & $\begin{array}{l}0.10 \\
0.14\end{array}$ \\
\hline
\end{tabular}

Data are the mean \pm S.D. or values for pooled samples of three rats given $20 \mathrm{mg} / \mathrm{kg}$ dose of the labeled compound. 
Table 3 Cumulative excretion of ${ }^{14} \mathrm{C}$ in urine, feces and bile after po administration of ${ }^{14} \mathrm{C}-\mathrm{TC}-80$ to rats and dogs

\begin{tabular}{|c|c|c|c|c|c|}
\hline \multirow{2}{*}{ Species } & \multirow{2}{*}{$\begin{array}{l}\text { Time after } \\
\text { dosage }(\mathrm{h})\end{array}$} & \multicolumn{3}{|c|}{ Cumulative excretion of ${ }^{14} \mathrm{C}(\%$ of dose) into: } & \multirow{2}{*}{$\begin{array}{c}\text { Total }{ }^{14} \mathrm{C} \text { recovered } \\
(\% \text { of dose })\end{array}$} \\
\hline & & Urine & Feces & Bile & \\
\hline \multirow[t]{5}{*}{ Rat } & 4 & $11.5 \pm 9.1$ & ND & ND & ND \\
\hline & 8 & $31.3 \pm 9.8$ & ND & ND & ND \\
\hline & 24 & $53.7 \pm 3.0$ & $40.4 \pm 1.0$ & ND & $94.0 \pm 2.4$ \\
\hline & 48 & $55.1 \pm 2.9$ & $43.2 \pm 1.1$ & ND & $98.3 \pm 2.0$ \\
\hline & 72 & $55.3 \pm 3.0$ & $43.4 \pm 1.1$ & ND & $98.6 \pm 2.0$ \\
\hline \multirow[t]{3}{*}{ Rat* } & 4 & $3.9 \pm 1.0$ & ND & $19.6 \pm 4.2$ & ND \\
\hline & 8 & $7.6 \pm 0.7$ & ND & $28.3 \pm 5.8$ & ND \\
\hline & 24 & $18.8 \pm 0.8$ & $26.4 \pm 12.0^{\dagger}$ & $45.1 \pm 9.4$ & $90.2 \pm 6.6$ \\
\hline \multirow[t]{5}{*}{ Dog } & 8 & $1.9 \pm 0.3$ & $\mathrm{ND}$ & ND & ND \\
\hline & 24 & $4.5 \pm 1.9$ & $58.3 \pm 24.2$ & ND & $62.8 \pm 25.0$ \\
\hline & 48 & $5.6 \pm 2.3$ & $91.5 \pm 1.5$ & ND & $97.1 \pm 2.8$ \\
\hline & 72 & $5.7 \pm 2.3$ & $92.0 \pm 1.7$ & ND & $97.7 \pm 2.8$ \\
\hline & 96 & $5.7 \pm 2.3$ & $92.1 \pm 1.7$ & ND & $97.8 \pm 2.7$ \\
\hline \multirow[t]{3}{*}{ Dog* } & 4 & ND & ND & $8.7 \pm 1.9$ & ND \\
\hline & 8 & $0.7 \pm 0.4$ & ND & $16.4 \pm 8.0$ & ND \\
\hline & 24 & $7.6 \pm 1.2$ & $48.6 \pm 10.2^{* *}$ & $32.1 \pm 4.8$ & $88.3 \pm 11.7$ \\
\hline
\end{tabular}

Data are the mean \pm S.D. of three or four animals given $20 \mathrm{mg} / \mathrm{kg}$ dose of the labeled compound.

* Biliary-cannulated rats or dogs (id administration)

** Contain gastrointestinal contents. ND, Not determined

Table 4 Composition of ${ }^{14} \mathrm{C}$-materials in urine, feces and bile after po administration of ${ }^{14} \mathrm{C}-\mathrm{TC}-80$ to rats and dogs

\begin{tabular}{|c|c|c|c|c|c|c|c|c|c|c|c|}
\hline \multirow{2}{*}{ Species } & \multirow{2}{*}{ Sample } & \multirow{2}{*}{$\begin{array}{c}\text { Total }{ }^{14} \mathrm{C} \\
(\% \text { of dose) }\end{array}$} & \multicolumn{9}{|c|}{ Composition of ${ }^{14} \mathrm{C}\left(\%\right.$ of total $\left.{ }^{14} \mathrm{C}\right)$} \\
\hline & & & TC-80 & I & II & III & IV & $\nabla$ & VI & VII & Others \\
\hline \multirow[t]{3}{*}{ Rat } & $24 \mathrm{~h}$ urine & $53.7 \pm 3.0$ & 0.1 & $54.9^{*}$ & 11. $2^{*}$ & $0.7^{*}$ & $0.3^{*}$ & 6.5 & $1.2^{*}$ & $5.9^{*}$ & 19.2 \\
\hline & $24 \mathrm{~h}$ feces & $40.4 \pm 1.0$ & 50.2 & 7.8 & 0.2 & 5.1 & 4.1 & 2.0 & 0.9 & 3.9 & 25.8 \\
\hline & $24 \mathrm{~h}$ bile** & $45.1 \pm 9.4$ & 0.1 & $54.7^{*}$ & $2.6^{*}$ & $6.5^{*}$ & 2. $9^{*}$ & 2.6 & $0.4^{*}$ & 3. $7^{*}$ & 26.5 \\
\hline \multirow[t]{3}{*}{ Dog } & $48 \mathrm{~h}$ urine & $5.6 \pm 2.3$ & 0.1 & $40.9^{*}$ & $6.0^{*}$ & 0.1 & $<0.1$ & 4.0 & $5.3^{*}$ & 3. $0^{*}$ & 40.6 \\
\hline & $48 \mathrm{~h}$ feces & $91.5 \pm 1.5$ & 82.5 & 6.7 & 0.5 & 0.3 & 1.8 & $<0.1$ & $<0.1$ & $<0.1$ & 8.2 \\
\hline & $24 \mathrm{~h}$ bile** & $32.1 \pm 4.8$ & 0.3 & $65.8^{*}$ & $4.0^{*}$ & 1. $0^{*}$ & 8. $6^{*}$ & 0.6 & $0.6^{*}$ & $0.5^{*}$ & 18.6 \\
\hline
\end{tabular}

Data are the mean \pm S.D. or values for pooled samples of the animals shown in Table 3 .

* Contain glucuronic and/or sulfuric acid conjugates ** Id administration

detectable amount of ${ }^{14} \mathrm{C}$ was excreted in the respiratory air of rats given the labeled compound po.

3.5.2 Biliary excretion and reabsorption

In biliary-cannulated rats and dogs given ${ }^{14} \mathrm{C}-$ TC-80 id, 45 and $32 \%$ of the dose, respectively, were excreted in the $24 \mathrm{~h}$ bile (Table 3 ). This finding indicated that the fecal excretion in intact rats and dogs in part was via the hepatobiliary route. To examine the presence of enterohepatic cycling of the biliary ${ }^{14} \mathrm{C}$, the radio- active bile of rats was injected into three other rats id. In $24 \mathrm{~h}, 51.0 \pm 10.5$ and $32.4 \pm 14.7 \%$ of the dosed ${ }^{14} \mathrm{C}$ were excreted in bile and urine, respectively. Thus it was obvious that the ${ }^{14} \mathrm{C}$ materials in bile were reabsorbed and excreted partly in bile, and the cycle continued until they were eliminated in feces.

\subsubsection{Metabolite composition}

Carbon-14-materials in urine, feces and bile were quantitatively determined by TLC and HPLC (Table 4). In both rats and dogs, only 
small amounts of unaltered TC-80 were detectable in urine and bile, with the remainder consisting metabolites, unconjugated or conjugated with glucuronic and/or sulfuric acid. This finding demonstrated that TC-80 absorbed was almost completely metabolized in the bodies of these animals. In both animals, I was the major metabolite found in urine and bile. Appreciable amounts of unchanged TC-80 were detected in feces of both rats and dogs. TLC of the gastrointestinal contents of biliary-cannulated rats and dogs indicated that the ${ }^{14} \mathrm{C}$ was derived exclusively from unmetabolized ${ }^{14} \mathrm{C}-\mathrm{TC}-80$. It was therefore evident that the compound did not undergo metabolic conversion in the gut and also that TC-80 detected in the feces of intact animals was due to the compound unabsorbed.

\section{Conclusion}

${ }^{14} \mathrm{C}-\mathrm{TC}-80$ administered to rats po is well absorbed from small intestine via the portal route, distributed widely in tissues, metabolized extensively by oxidation, and eliminated from the body preferentially in urine, with the remainder appearing in feces via hepatobiliary route. The absorption of po ${ }^{14} \mathrm{C}-\mathrm{TC}-80$ is less effective in dogs than in rats. In dogs, the compound absorbed is metabolized in the same way as in rats and the metabolites formed are eliminated largely in feces, together with unabsorbed TC-80.

\section{References}

1) Uemura, I., Shibata, K., Hirano, Y. et al.: Jpn. Pharmacol. Ther., submitted

2) Takenaka, M., Nakata, M., Tsuboi, S. and Fujita, T.: "Vitamin D, Chemical, Biochemical and Clinical Endocrinology of Calcium Metabolism", p. 607, Walter de Guyter \& Co., Berlin-New York (1982)

3) Yamazaki, I.: Program of the 7th International Congress of Endocrinology, p. 1628 (1984)

4) Yoshida, K., Tsukamoto, T., Torii, H. et al.: Radioisotopes, 34, 612-617 (1985)

5) Tanayama, S., Shirakawa, Y., Kanai, Y. and Suzuoki, Z.: Xenobiotica, 4, 33-47 (1974)

6) Tanayama, S., Kobayashi, T. and Kanai, Y.: ibid., 8, 365-375 (1978)

7) Tanayama, S., Yoshida, K., Adachi, K. and Kondo, T.: Antimicrob. Agents Chemother., 18, 511-518 (1980)

\title{
要 旨
}

\section{イプリフラボン(TC-80)のラットとイヌにおける生体内動態}

\author{
吉田清志, 塚本剛司, 鳥井 洋, 土井孝良, 苗代一郎, 柴田邦彦*, 植村家顕*, 棚山薰晴 \\ 武田薬品工業(㑣中央研究所 \\ 532 大阪市淀川区十三本町 2-17-85 \\ *野村生物科学研究所 247 鎌倉市梶原 4-7-1
}

\footnotetext{
${ }^{14} \mathrm{C}$-イプリフラボンをラットに経口投与すると，血漿中 ${ }^{14} \mathrm{C}$ 濃度は 1.5 時間で最大となり，半減期 は5.8時間であった。イヌに経口投与時の血漿中 ${ }^{14} \mathrm{C}$ は 0.5 時間でピークとなり，以後徐々に低下 した。これらの動物の血漿中には未変化体は少なく,大部分が代謝物であった。ラットにおいて ${ }^{14} \mathrm{C}$ は体内の各組織に広く分布し，その濃度は肝藏，腎臓と消化管で比較的高かった。イプリフラボン のラット大腿骨への分布も認められた。排泄はラットで48時間，イヌでは72時間で終了し，大部分 は代謝物として排泄された。ラットでは䔬よりも尿に多く排泄されたが，イヌでは逆に䔬に排泄さ れる割合が多かった。これらの動物において ${ }^{14} \mathrm{C}$ の胆汁排泄と腸肝循環も観察された。
} 